\title{
Morphological Characterization of Potentially Pathogenic Thermophilic Amoebae Isolated From Surface Water in Mashhad, Iran
}

\author{
Mohammad Reza Mahmoudi ${ }^{1}$; Fariba Berenji ${ }^{2, *}$; Abdolmajid Fata ${ }^{2}$; Mohammad Javad \\ Najafzadeh $^{2}$; Amin Asadian ${ }^{2}$; Maryam Salehi ${ }^{3}$ \\ ${ }^{1}$ Department of Microbiology and Parasitology, Faculty of Medicine, Guilan University of Medical Sciences, Rasht, IR Iran \\ ${ }_{3}^{2}$ Department of Parasitology, School of Medicine, Mashhad University of Medical Sciences, Mashhad, IR Iran \\ ${ }^{3}$ Department of Community Medicine, School Of Medicine, Mashhad University of Medical Sciences, Mashhad, IR Iran \\ ${ }^{*}$ Corresponding author. Fariba Berenji, School of Medicine, Mashhad University of Medical Sciences, Mashhad, IR Iran. Tel:+98-5138022235, Fax: +98-5138547255, E-mail: Berenjif@mums.ac.ir
}

Received: December 9, 2014; Revised: February 22, 2015; Accepted: March 15, 2015

Keywords: Acanthamoeba; Iran; Encephalitis

\section{Dear Editor,}

Free living amoebae (FLA) are frequently distributed in environment, such as air, water, dust and soil (1). Some strains of Acanthamoeba spp. are non-pathogen, while others are pathogenic in immunocompromised patients or even healthy persons (2-4). Acanthamoeba encephalitis is rare and less likely to be diagnosed with successful medical intervention. These amebas can carry and transmit important and pathogenic bacteria such as Vibrio cholera and Legionella (5). Since there was not any information about distribution of Acanthamoeba in Mashhad City, the main objective of the present research was investigating the presence of potentially pathogenic Acanthamoeba genus by morphological criteria and temperature tolerance assays in water sources of Mashhad, Iran.

Between December 2012 to June 2013, 61 water samples were collected randomly from squares and ponds of parks of 13 regions of Mashhad, Iran. For each sample, approximately $500 \mathrm{~mL}$ of water was filtered through $0.45 \mu \mathrm{m}$ pore-size cellulose nitrate membranes. Then the filter was cultured on Non-nutrient agar enriched with Escherichia coli (NNA) prepared with Amoeba Page Saline (6). Then the plate was sealed with parafilm and incubated at the respective temperatures. Two plates from each of the sampling point and subculture were incubated at room temperature $\left(25-28^{\circ} \mathrm{C}\right)$ and $37^{\circ} \mathrm{C}$, respectively. Identification of the obtained Acanthamoeba spp. was achieved according to morphological characteristics of both trophic and cyst stages (Figure 1).

In the present study, in 15 samples, free-living amoebae grown at room temperature and 6/61 (9.8\%) of the total examined water samples had positive results at $37^{\circ} \mathrm{C}$. In this study, some of these free living amebas were potentially pathogenic according to morphological criteria and thermotolerant assay. Moreover, Acanthamoeba is introduced as a vehicle for circulation of different pathogens viruses and bacteria such as Legionella, Pseudomonas and Helicobacter between human and environments (7-9). Human activity was seen in all of the localities from which samples were taken. Therefore it is necessary to prevent potential contamination of water resources with free-living amebas and infectious agents using new disinfectant and treatment methods. Since the holy city of Mashhad receives millions of pilgrims annually, it is necessary to provide sufficient information for preventing contamination, especially in high risk groups by public health organizations. Recently, molecular characteristics are more accurate for genotyping these organisms. Therefore, further study is needed to confirm pathogen and non-pathogen amoebas by molecular and sequencing methods in Mashhad.

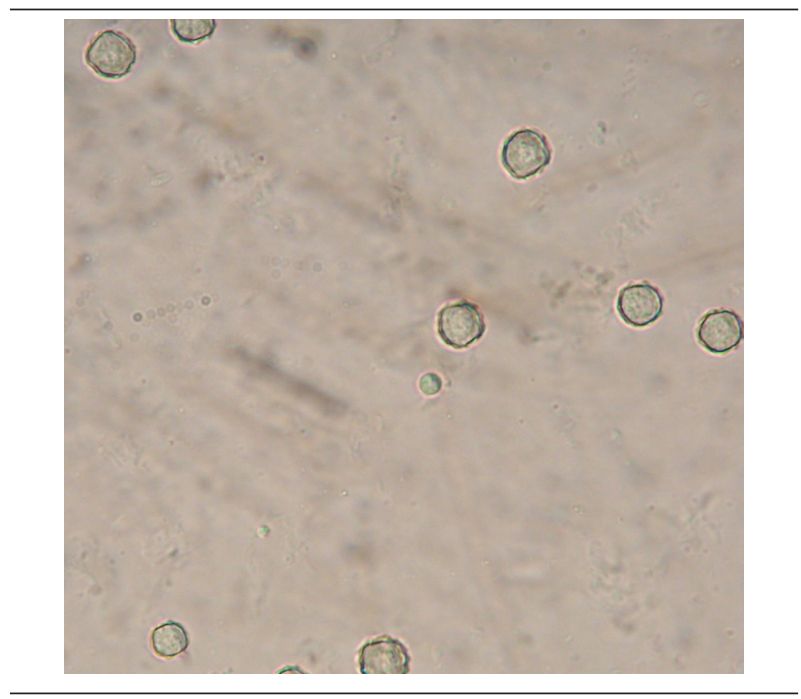

Figure 1. Cyst of Acanthamoeba Species After Isolation From Water Samples and Cultivation; $\times 400$, (Authors Source)

Copyright (C) 2015, Ahvaz Jundishapur University of Medical Sciences. This is an open-access article distributed under the terms of the Creative Commons Attribution-NonCommercial 4.0 International License (http://creativecommons.org/licenses/by-nc/4.0/) which permits copy and redistribute the material just in noncommercial usages, provided the original work is properly cited. 


\section{Acknowledgements}

The results presented in this paper obtained from a project, with the ID number of "910578." The authors appreciate the Research Council of Mashhad University of Medical Sciences for their financial support.

\section{Authors' Contributions}

Study concept and design: Fariba Berenji and Abdolmajid Fata. Acquisition of data: Maryam Salehi, Mohammad Reza Mahmoudi and Fariba Berenji. Analysis and interpretation of data: Fariba Berenji and Mohammad Reza Mahmoudi. Drafting of the manuscript: Mohammad Reza Mahmoudi. Critical revision of the manuscript for important intellectual content: Fariba Berenji. Statistical analysis: Maryam Salehi. Administrative, technical and material supports: Mohamma Javad Najafzadeh and Amin Asadian. Study supervision: Mohammad Reza Mahmoudi.

\section{References}

1. Visvesvara GS, Moura H, Schuster FL. Pathogenic and opportu- nistic free-living amoebae: Acanthamoeba spp., Balamuthia mandrillaris, Naegleria fowleri, and Sappinia diploidea. FEMS Immunol Med Microbiol. 2007;50(1):1-26.

2. Khan NA. Pathogenesis of Acanthamoeba infections. Microb Pathog. 2003;34(6):277-85.

3. Marciano-Cabral F, Cabral G. Acanthamoeba spp. as agents of disease in humans. Clin Microbiol Rev. 2003;16(2):273-307.

4. Martinez AJ. Infection of the central nervous system due to Acanthamoeba. Rev Infect Dis. 1991;13 Suppl 5:S399-402.

5. Pagnier I, Raoult D, La Scola B. Isolation and identification of amoeba-resisting bacteria from water in human environment by using an Acanthamoeba polyphaga co-culture procedure. Environ Microbiol. 2008;10(5):1135-44.

6. Mahmoudi MR, Taghipour N, Eftekhar M, Haghighi A, Karanis P. Isolation of Acanthamoeba species in surface waters of Gilan province-north of Iran. Parasitol Res. 2012;110(1):473-7.

7. Lorenzo-Morales J, Lopez-Darias M, Martinez-Carretero E, Valladares B. Isolation of potentially pathogenic strains of Acanthamoeba in wild squirrels from the Canary Islands and Morocco. Exp Parasitol. 2007;117(1):74-9.

8. Al-Herrawy A, Bahgat M, Mohammed A, Ashour A, Hikal W. Morpho-Physiological and Biochemical Criteria of Acanthamoeba spp. Isolated from the Egyptian Aquatic Environment. Iran J Parasitol. 2013;8(2):302-12.

9. Rahdar M, Niyyati M, Salehi M, Feghhi M, Makvandi M, Pourmehdi $\mathrm{M}$, et al. Isolation and genotyping of acanthamoeba strains from environmental sources in ahvaz city, khuzestan province, southern iran. Iran J Parasitol. 2012;7(4):22-6. 